\title{
CO FIRE (COCO FIBER PILLOW WITH RELAXING AROMATIC SYSTEM) : INOVASI PENGOLAHAN LIMBAH SABUT KELAPA MENJADI KREASI BANTAL MOTIF BATIK CIPRAT DENGAN SEDIAAN AROMATERAPI BERBASIS SOCIO ENTREPRENEURSHIP
}

\author{
Feny Yuliana Andriani ${ }^{1}$, Dwi Adi Purnama ${ }^{2}$, Ines Widyarani ${ }^{3}$, Muhammad Rizal ${ }^{4}$, Eva \\ Altayani ${ }^{5}$ \\ 1,2,4,5 Prodi Teknik Industri, Fakultas Teknologi Industri, Universitas Islam Indonesia \\ ${ }^{3}$ Jurusan Farmasi, Fakultas Matematika dan IImu Pengetahuan Alam, Universitas Islam \\ Indonesia \\ Yogyakarta
}

\begin{abstract}
ABSTRAK
COFIRE merupakan upaya dalam mengurangi limbah sabut kelapa dengan memanfaatkannya menjadi bantal edukasi berbasis kebudayaan dengan menggunakan kain batik ciprat hasil karya anak disabilitas sebagai pelapis bantal dan pemberian aroma terapi olahan tanaman Lavender. Yogyakarta merupakan salah satu kawasan yang kaya akan potensi perkebunan kelapa. Masyarakat Yogyakarta dapat meningkatkan kesejahteraan melalui bisnis ini. Pemanfaatan sabut kelapa salah satunya dapat dijadikan sebagai pengganti penggunaan dacron dan kapuk berlebih pada isi bantal. Dacron dan kapuk berlebih memiliki dampak negatif bagi kesehatan manusia. Disisi lain, bantal aromaterapi dapat mengurangi tingkat insomnia pada masyarakat. Aroma terapi dihasilkan dari tanaman Lavender yang telah melalui proses destilasi uap dan kromatografi gas sehingga akan menghsilkan minyak astiri Lavender. Aromaterapi diberikan pada bahan utama yaitu sabut kelapa dan juga terdapat filter aromaterapi yang dapat diisi kembali ketika sudah habis sehingga pengguna dapat nyaman saat menggunakan bantal ini. Penjahitan produk sabut kelapa ini menggunakan socio entrepeneurship lulusan anak berkebutuhan khusus untuk meningkatkan pendapatan mereka secara finansial.
\end{abstract}

Kata kunci: Aromaterapi, Bantal, Sabut Kelapa

\section{PENDAHULUAN}

ASEAN Economic Community (AEC) atau yang lebih sering dikenal dengan Masyarakat Ekonomi ASEAN (MEA) merupakan bentuk integrasi ekonomi ASEAN dengan sistem perdagangan bebas yang terjadi antar negara-negara ASEAN yang dibentuk pada saat memasuki tahun 2015 (Suroso, 2015). Indonesia merupakan salah satu negara yang bergabung dalam Masyarakat Ekonomi ASEAN (MEA). Terbentuknya MEA memberikan beberapa tantangan bagi Indonesia mengenai tenaga kerja dalam negeri. Jumlah lapangan pekerjaan bagi tenaga kerja dalam negeri akan semakin sedikit sehingga dapat meningkatkan tingkat pengangguran di Indonesia. Menurut
Badan Pusat Statistik (BPS) pada tahun 2014 mencapai 5,33 juta orang. Dalam upaya mengurangi pengangguran tenaga kerja Indonesia, diperlukan strategi yang baik dengan memanfaatkan peluang bisnis MEA. Salah satu strategi yang dapat dilakukan adalah dengan membangun sektor ekonomi UMKM (Usaha Mikro Kecil Menengah). Sektor perkebunan yang berada di kawasan pedesaan masih menjadi rantai terlemah melihat rendahnya tingkat produktivitas masyarakat dan tingginya pengangguran masyarakat perkebunan yang dapat mengakibatkan rendahnya taraf ekonomi pedesaan (Budianta, 2010). 
Kelapa merupakan salah satu tanaman yang memilki nilai ekonomis tinggi. Buah kelapa memiliki empat komponen penting diantaranya adalah sabut kelapa sebanyak 35 persen, tempurung kelapa sebanyak 12 persen, daging buah sebanyak 28 persen dan air kelapa sebanyak 25 persen (Mulyawan, et al., 2015). Yogyakarta merupakan salah satu daerah yang kaya akan potensi perkebunan kelapa. Berdasarkan data Badan Pusat Statistik (BPS), Kabupaten Kulonprogo memiliki perkebunan kelapa terluas dibandingkan dengan beberapa kabupaten/kota di D.I Yogyakarta seperti Bantul, Gunungkidul, Sleman dan Yogyakarta.

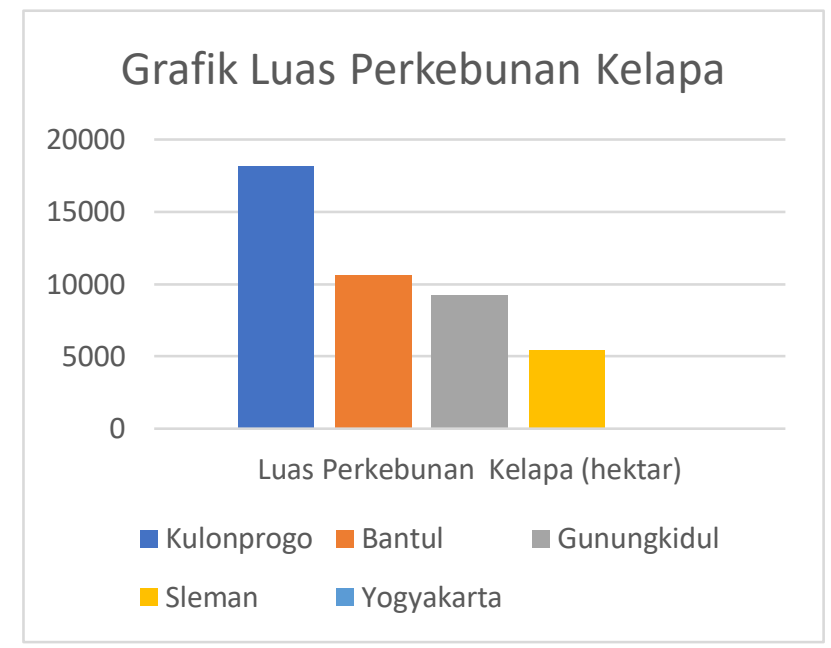

Gambar 1.1 Luas Perkebunan Kelapa Yogyakarta (Sumber: BPS 2014)

Pemanfaatan kelapa pada umumnya hanya dimanfaatkan bagian buah dan airnya saja sehingga limbah sabut kelapa hanya ditumpuk dan dibuang tanpa adanya pemanfaatan lebih lanjut menjadi produk yang bernilai. Sabut kelapa merupakan komponen limbah terbesar yang terdapat pada buah kelapa.

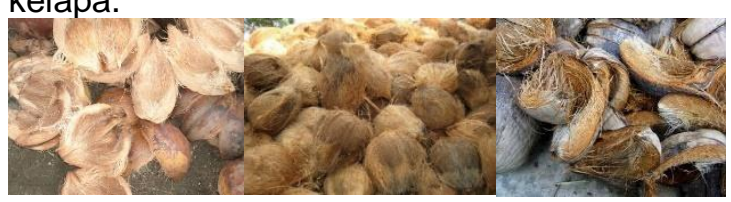

Gambar 1.2 Limbah sabut kelapa

Pemanfaatan limbah sabut kelapa selama ini sebagian besar hanya dimanfaatkan sebagai bahan baku pembuatan keset. Banyak produk yang dapat dihasilkan dari pemanfaatan sabut kelapa salah satunya adalah dapat dijadikan sebagai pengganti dacron dan kapuk pada isi bantal.

Dacron dan kapuk sering digunakan sebagai isi bantal karena memiliki sifat yang elastis, harga terjangkau dan berstrektur lembut. Akan tetapi dibalik kelebihan tersebut, terdapat bahaya yang ditimbulkan dari dacron dan kapuk bagi kesehatan manusia. Dari segi kesehatan, kapuk merupakan tempat bersarangnya hewan kecil seperti tungau dan dapat menimbulkan alergi. Sama halnya dengan dacron yang dapat meninggalkan debu di dalamnya sehingga berbahaya bagi kesehatan manusia (Hartini, et al., 2013). Disisi lain, bantal harus menciptakan kenyamanan bagi penggunanya salah satunya adalah dapat mengurangi tingkat insomnia. Insomnia merupakan gangguan tidur yang disebabkan oleh beberapa faktor seperti depresi, kelelahan, faktor psikologis (Susanti, 2011). Upaya mengurangi tingkat insomnia adalah dengan menggunakan aromaterapi. Aromaterapi yang diberikan merupakan hasil olahan dari tanaman lavender yang dapat memberikan efek relaksasi dan sedatif karena mengandung ester yang dapat memudahkan tidur (Kusnanto, et al., 2007).

Selain itu, masyarakat ekonomi ASEAN mengintegrasikan perdagangan bebas antara negara anggota ASEAN (Setiawan A. , 2016). Sehingga, semakin berkembangnya MEA maka dibutuhkan produk khas Indonesia yang dapat menempuh pasar bebas sehingga COFIRE menawarkan konsep kebudayaan Indonesia dengan kreasi motif Aksara Jawa dan penggunaan kain Batik Ciprat hasil produksi anak disabilitas sehingga dapat meningkatkan kreatifitas anak disabilitas dan mendorong anak disabilitas berkontribusi bersama dalam kegiatan wirausaha dalam tujuan socio enterpreneurship.

Berdasarkan permasalahan tersebut, salah satu solusi untuk mengurangi limbah sabut kelapa adalah dengan memanfaatkan limbah sabut kelapa menjadi produk COFIRE (Coco Fiber Pillow with Relaxing Aromaterapic System) : Inovasi Pengolahan Limbah Sabut Kelapa menjadi Ragam Kreasi Bantal Motif Aksara Jawa dan Batik 
Ciprat Modern dengan Sediaan Aromaterapi Berbasis Socio Entrepreneurship. Produk CO FIRE dapat menjadi solusi dalam mengurangi limbah sabut kelapa dan memberikan kenyaman bagi penggunanya.

\section{METODE PENELITIAN}

Penelitian ini berdasarkan pada kondisi yang terjadi di lapangan dan sesuai dengan pengamatan peneliti mengenai penumpukan limbah yang terjadi di daerah Yogyakarta. Metode pengumpulan data dalam penelitian ini adalah observasi secara langsung mengenai limbah kelapa, pembuatan aromaterapi dan pembuatan batik ciprat oleh anak disabilitas. Selain itu sumber data yang digunakan adalah data sekunder seperti data-data yang berasal dari jurnal, buku maupun peneltianpenelitian sebelumnya.

Adapun metode yang dilakukan dalam proses pembuatan aroma terapi Lavender adalah sebagai berikut:

Sistematika kerja pada pembuatan arimaterapi ini berisi urutan proses pembuatan aromaterapi dari tanaman lavender dan tanaman sereh dengan menggunakan metode destilasi uap serta dilakukan identifikasi minyak atsiri dengn kromatografi lapis tipis (KLT) dan kromatogrfi gas.

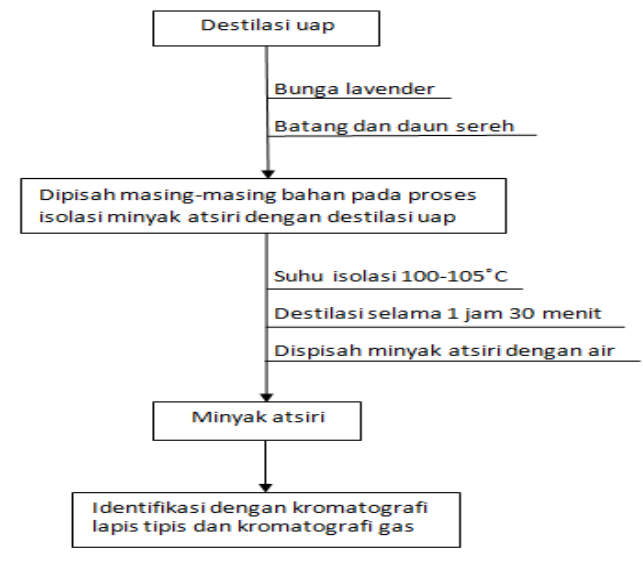

Gambar 1.3 Pembuatan Aromaterapi Lavender

Cara Kerja dalam metode pembutan aromaterapi Lavender adalah sebagai berikut:

1. Pembuatan minyak atsiri

Bahan pda tumbuhan lavender ditimbang dan bahan tumbuhan sereh di potong telebih dahulu dan ditimbang kemudian dimasukkan ke alat destilasi, destilasi selama 1 jam 30 menit dengan suhu berkisar $100-105^{\circ} \mathrm{C}$. Minyak atsiri yang di peroleh di pisahkan dari air dan disimpan didalam wadah yang tertutup.

2. Identifikasi minyak atsiri dengan kromatografi lapis tipis (KLT) pada tanaman lavender.

Siapkan plat KLT yang akan digunakan, ditotolkan larutan minyak lavender (standar) dan larutan minyak atsiri lavender pada plat KLT yang tersedia dengan menggunakan pipa kapiler. Kemudian plat yang telah ditotoli standar dan minyak atsiri dilakukan elusi dengan fase gerak N-heksan : etil asetat (7:3). Dikeringkan plat KLT dan selanjutnya disemprot penampak bercak anisaldehida pekat dan larutan $\mathrm{FeCL}_{3}$. Diamati bercak tersebut dan di bandingkan hasil KLT minyak atsiri dan standar.

3. Identifikasi minyak atsiri dengan kromatografi lapis tipis (KLT) pada tanaman sereh.

Siapkan plat KLT yang akan digunakan, ditotolkan larutan minyak citronella (standar) dan larutan minyak atsiri sereh pada plat KLT yang tersedia dengan menggunakan pipa kapiler. Kemudian plat yang telah ditotoli standar dan minyak atsiri dilakukan elusi dengan fase gerak N-heksan : etil asetat (7:3). Dikeringkan plat KLT dan selanjutnya disemprot penampak bercak anisaldehida pekat dan larutan $\mathrm{FeCL}_{3}$. Diamati bercak tersebut dan di bandingkan hasil KLT minyak atsiri dan standar.

4. Identifikasi kandungan senyawa minyak atsiri daun sereh dan lavender dengan kromatografi gas

Dimasukkan $1 \mathrm{ml}$ minyak atsiri hasil destilasi didalam vial khusus untuk kromatografi gas. Dilakukan pengamatan selama proses identifikas. Kemudian di catat parameter yang digerakan dalam identifikasi tersebut. Dibandingkan data hasil kromatografi gas yang diperoleh dengan library yang telah tersedia untuk mengukur jenis kandungan senyawa kimia minyak atsiri hasil destilasi daun sereh dan bunga lavender.

\section{HASIL DAN PEMBAHASAN}


Bantal sabut kelapa terdapat dua jenis desain dimana menggunakan bahan yang lembut pada bagian luar, serta menggunakan motif aksara jawa maupun batik ciprat modern pada bagian atas dan bawah bantal dengan desain bordir untuk memperkenalkan aksara jawa di kalangan masyarakat, serta setiap orang hingga tuna netra dapat mengerti aksara jawa melalui tulisan bordir.

Aromaterapi diberikan pada bahan utama yaitu sabut kelapa dan juga terdapat filter aromaterapi yang dapat diisi kembali ketika sudah habis sehingga pengguna dapat nyaman saat menggunakan bantal ini.

Penjahitan produk sabut kelapa ini menggunakan socio entrepeneurship lulusan anak berkebutuhan khusus untuk meningkatkan pendapatan mereka secara finansial.

Berikut merupakan konsep produk $\mathrm{CO}$ FIRE yang merupakan inovasi baru bantal sabut kelapa dengan sediaan aromaterapi menggunakan ragam kreasi aksara jawa dan batik ciprat modern.

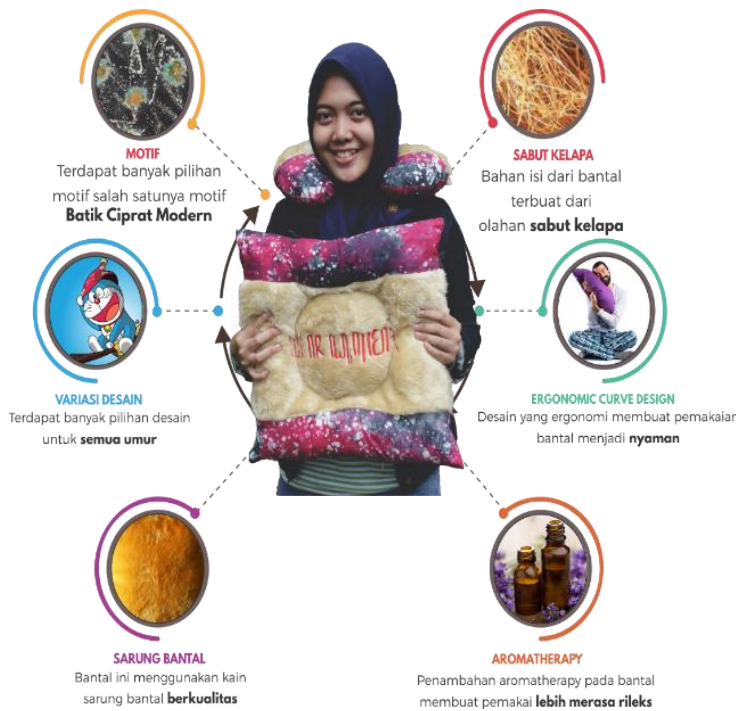

Gambar 3.1. Desain Co Fire

CO FIRE diharapkan dapat menjadi produk industri kreatif yang unggul di bidang pertanian. Beberapa keunggulan Co FIRE adalah sebagai berikut:

\section{Innovative}

Merupakan produk innovative dengan menggabungkan konsep daur ulang limbah sabut kelapa dan memperkenalkan kebudayaan Indonesia dengan memanfaatkan batik ciprat serta menjadi produk yang bermanfaat bagi kesehatan dengan pemberian aroma terapi dalam upaya mengurangi tingkat insomnia.

\section{Ergonomic Design}

Co Fire memiliki desain yang ergonomi sesuai dengan ukuran antropometri. Desain Co Fire terdiri dari ergonomic curve design yang berfungsi sebagai penyangga kepala agar terciptanya kenyamanan saat tidur.

\section{Aesthetics}

Selain mempertimbangkan desain ergonomi, Co Fire juga memberikan desain yang menarik dengan menggunakan kain batik ciprat dan motif aksara Jawa sehingga menghasilkan produk yang menarik dan beredukasi dengan konsep kebudayaan.

Eco-friendly

Produk ini dibuat dengan memanfaatkan limbah sabut kelapa sebagai bahan baku utamanya yang ramah lingkungan sehingga mudah untuk di reuse, recycle, and reduce. Disisi lain, pemanfaatan limbah juga bertujuan untuk mengurangi limbah di lingkungan tersebut.

\section{Manfaat aromaterapi}

$\mathrm{Di}$ indonesia pengobatan alternatif sedang berkembang dengan pesat. Salah satu pengobatan alternatif dengan menggunakan aromaterapi yang menggunakan minyak esensial dari berbagai tanaman di Indonesia. Aromaterapi dikenal mampu menghilangkan stress, mampu mengatur emosional setiap individu,mengatasi kegelisahan, mengatasi insomnia, meremajakan dan meregenerasi sel pada setiap individu yang bekerja setiap hari serta mampu meningkatkan kesehatan dan kesejahteraan tubuh, pikiran, dan jiwa.

Aromaterapi dalam penelitian lain juga mampu meningkatkan fungsi memori otak dengan menghirup (Sofiani dan Pratiwi, 2017). Molekul-molekul dari minyak aromaterapi mudah menguap, sehingga dapat bereaksi langsung dengan indra penciuman kemudian diteruskan ke otak. Bau yang dihirup mengaktifkan pelepasan neurotransmitter seperti serotonin, endorfin, dan norepinephrine dan memodulasi neuroreceptors. Norepinephrine juga berperan penting 
dalam memori. Reseptor di hidung juga berkomunikasi dengan bagian otak (amigdala dan hipokampus) yang berfungsi sebagai gudang untuk emosi dan kenangan (budje, 2008).

Di zaman yang modern ini salah satu aroamterapi yang banya di sukai adalah lavender dan daun sereh. Aroamterapi dari lavender dipercaya mampu memberikan rasa kantuk dan berefek mampu merelaksai bagi saraf otot-otot yang tegang setelah melakukan aktivitas. Minyak lavender memiliki efek menenagkan dengan kandungan linalool-nya adalah salah satu minyak aromaterapi yang banyak digunakan saat ini, baik secara inhalasi (dihirup) ataupun dengan teknik pemijatan pada kulit. Pada saat kita menghirup suatu aroma, komponen kimianya akan masuk ke bulbus olfactory, kemudian ke limbic sistem pada otak. Limbic adalah struktur bagian dalam dari otak yang berbentuk seperti cincin yang terletak di bawah cortex cerebral. Tersusun ke dalam 53 daerah dan 35 saluran atau tractus yang berhubungan (He, L., dkk. (2010)).

Aromaterapi yang digunakan melalui cara inhalasi atau dihirup akan masuk ke sistem limbic dimana nantinya aroma akan diproses sehingga kita dapat mencium baunya (Muchtaridi, Jurnal Tek. Ind. Pert. Vol. 17(3),80-88). Hipocampus bertanggung jawab atas memori dan pengenalan terhadap bau juga tempat dimana bahan kimia pada aromaterapi merangsang gudanggudang penyimpanan memori otak kita terhadap pengenalan bau-bauan. limbic sebagai pusat nyeri, senang, marah, takut, depresi, dan berbagai emosi lainnya. Sistem limbic menerima semua informasi dari sistem pendengaran, sistem penglihatan, dan sistem penciuman. Sistem ini juga dapat mengontrol dan mengatur suhu tubuh, rasa lapar, dan haus. Amygdala sebagai bagian dari sistem limbic bertanggung jawab atas respon emosi kita terhadap aroma. (Barcelli E., dkk (2004)). Minyak sereh wangi (citronella oil) yang sering ditemukan didapurdapur rumah dapat bermanfaat menenangkan pikiran dan berkontribusi mengurangi stres serta membuat tidur menjadi lebih nyenyak karena sifat hipnosis minyak serai mampu membantu meningkatkan kualitas tidur.
Ramuan Sereh terdiri dari senyawa sehat minyak esensial, seperti nerol, sitronelol, myrcene, dipentene, geraniol dan metil heptenone yang memiliki sifat anti-jamur, insektisida dan antiseptik. Minyak banyak digunakan untuk aromaterapi karena efek terapeutik yang akan membantu merevitalisasi dan menyegarkan tubuh. Minyak sereh memiliki zat alami yang akan membantu merangsang sirkulasi darah dan meremajakan jaringan kulit. Hal ini juga membantu untuk mengangkat dan mengencangkan kulit yang lesu dan lelah. Sereh telah terbukti bisa menjadi tonik yang sangat baik untuk sistem saraf. Sereh dapat merangsang pikiran dan membantu untuk mengatasi kejangkejang, gugup, vertigo, mampu menenangkan ketika seseorang syok dan berbagai gangguan saraf seperti Alzheimer dan penyakit Parkinson. Sereh digunakan untuk mandi terapi, yang akan membantu untuk menenangkan saraf, mengurangi gejala depresi dan kelelahan yang disebabkan oleh stres. (Yuni Eko, dkk., 2013).

Permintaan Pasar dan Kebutuhan Konsumen

Perencanaan produk harus mempertimbangkan apakah produk yang mereka kembangkan dapat diterima konsumen, memuaskan konsumen, dan menjawab permintaan konsumen berkaitan dengan kebutuhannya akan produk tersebut. Ketika produk selesai didevelop dan siap untuk diluncurkan ke pasar, harapan tim pengembang hanya satu: pasar dapat menerima produk tersebut dan memberikan laba kepada perusahaan (Purba, 2009).

Untuk menangani permasalahan tersebut yang harus dilakukan adalah melakukan analisis menggunakan proses QFD atau Quality Function Development. Akao (1990) mendefinisikan QFD: "adalah suatu metode untuk mengembangkan suatu mutu desain yang diarahkan pada pemuasan kebutuhan pelanggan dan kemudian menerjemahkan keinginan konsumen tersebut kedalam target desain dan jaminan mutu utama yang digunakan di seluruh tahapan produksi". Dalam QFD terdapat metode untuk menentukan kebutuhan konsumen yakni metode $\mathrm{HOQ}$ atau House of Quality 
yang terdiri dari beberapa grafik. Grafik sangat penting dalam membangun 'House of Quality'. Dengan memakai grafik atau diagram, informasi yang didapat dari mendengar 'Voice of the customer' dapat diringkas dan dibandinkan untuk keperlun desain (Madu, 2006). Hal tersebut dikarenakan Features dan rancangan desain yang akan dikembangkan pada produk baru bukanlah masalah selera, opini, dan keinginan individu melainkan ada "suara" dari calon pelanggan yang sangat banyak dan beragam, yang harus "didengar" dan dianalisis dengan baik, ditambah dengan faktor lainnya yang cukup rumit dan kompleks, termasuk dalam persaingan bisnis yang ganas (Purba, 2009).

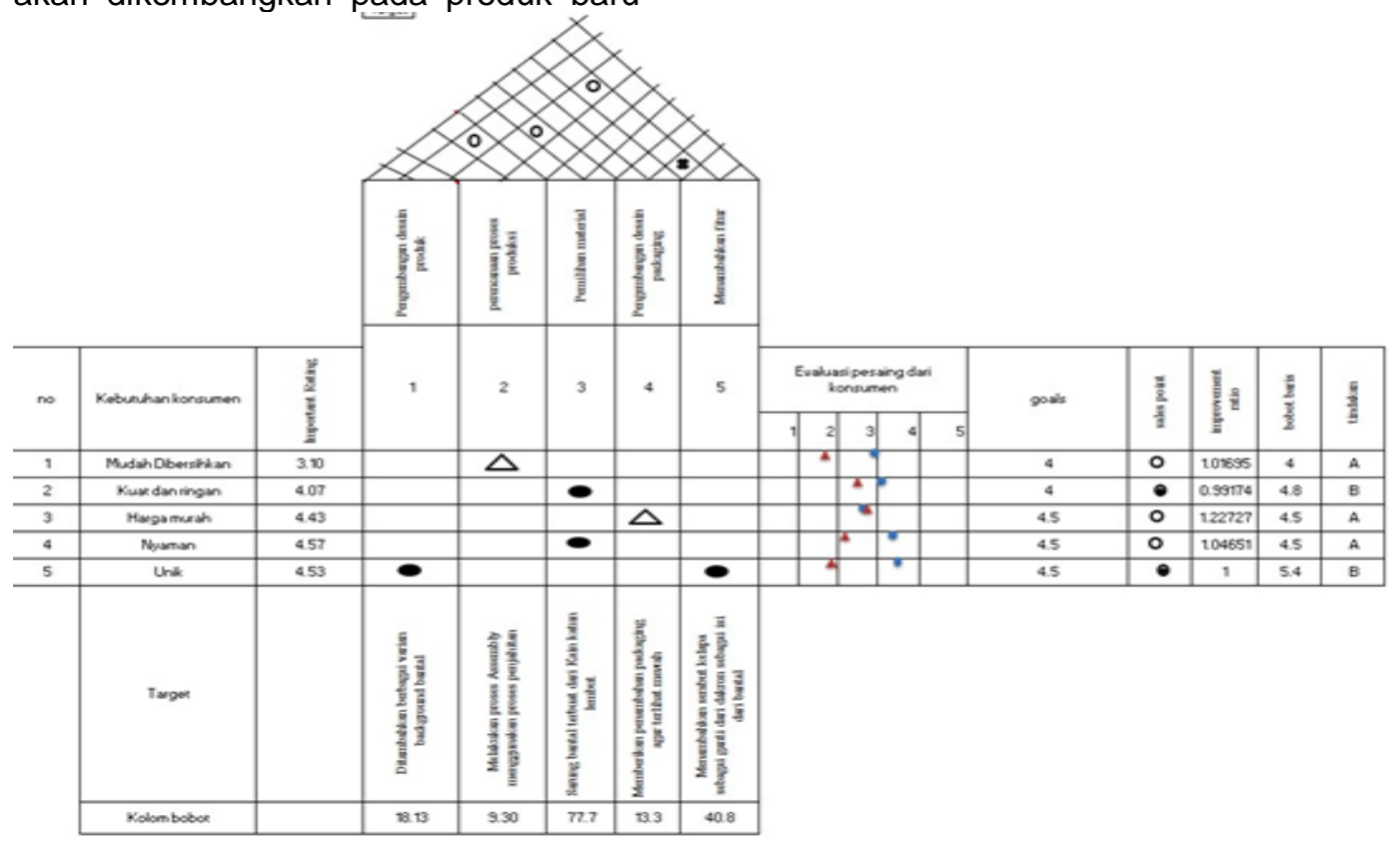

Pada tabel $H O Q$ dapat dilihat ratarata produk yang telah dikembangkan sudah lebih baik dari produk yang telah ada namun masih terdapat beberapa kekurangan yang harus diperbaiki. Dapat dilihat pada bagan HOQ pada bagian atas terdapat kolom berisi Perencanaanproses

produksi, Pengembangan desain packaging, Pemilihan Material, Pengembangan desain produk, dan Menambahkan fitur, kelima hal tersebut merupakan kelebihan-kelebihan yang dibuat pada produk bantal CO FIRE yang baru yang diusulkan pada bisnis ini. Pada bagian bawah dibaris "Target" berisi deskripsi dari kelebihan produk bantal yang tersedia. Pada bagian tengah terdapat kolom yang menghubungkan kriteria yang ada pada baris "Target" dan kolom "Kebutuhan konsumen". Pada bagian tengah tabel, persilangan antara "Ditambahkan berbagai varian background" dan "Unik" diberi tanda lingkaran penuh yang artinya hubungan antara keduanya kuat. Persilangan antara "Melakukan proses penjahitan " dan "Mudah dibersihkan" diberi tanda segitiga kosong yang artinya hubungan antara keduanya Lemah. Pada persilangan antara "Sarung bantal terbuat dari kain katun " dengan "Bahan kuat dan ringan" dan "Nyaman" diberi tanda lingkaran penuh yang artinya hubungan antara keduanya kuat. Persilangan antara "Pengembangan desain packaging" sehingga terlihat modern" dan "harga murah" diberi tanda segitiga yang artinya hubungan antara keduanya lemah. Pada persilangan antara "Penambahan serabut kelapa sebagai ganti dakron" dan "Unik" diberi tanda lingkaran penuh yang artinya hubungan antara keduanya kuat. Dapat dilihat kriteria konsumen dengan bahan kuat dan ringan serta mudah digunakan memiliki bobot baris dengan nilai 4.8 dan 5.4 yang berarti merupakan nilai tertinggi yang membuat pemberian tindakan untuk produk itu adalah B 
yakni mempertahankan kualitas secara kontinyu. Sementara kriteria Mudah dibersihkan, Harga murah, dan Nyaman memiliki nilai bobot baris 4 ,
4.5, dan 4.5 yang menurut peneliti harus diberikan tindakan $A$ yakni meningkatkan kualitas produk tersebut.

\section{Analisis Prospek Usaha}

Tabel 3.1 Analisis SWOT CO FIRE

\begin{tabular}{|c|c|c|}
\hline rOR & STRENGHT (S) & WEAKNESS (W) \\
\hline EFAS & $\begin{array}{l}\text { 1. Produk yang menjadi salah } \\
\text { satu solusi masalah } \\
\text { lingkungan limbah sabut } \\
\text { kelapa. } \\
\text { 2. Bahan baku yang bersifat } \\
\text { tahan lama. } \\
\text { 3. Produk yang memiliki wangi } \\
\text { aromaterapi sehingga dapat } \\
\text { membuat pikiran menjadi } \\
\text { relax. } \\
\text { 4. Berbasis Socio } \\
\text { Entropreneurship yang } \\
\text { memperkerjakan anak } \\
\text { disabilitas dan ibu rumah } \\
\text { tangga. }\end{array}$ & $\begin{array}{l}\text { 1. Desain bentuk yang } \\
\text { terbatas. } \\
\text { 2. Terdapat bahan baka } \\
\text { yang lebih empuk dari } \\
\text { sabut kelapa seperti } \\
\text { kapuk dan dacron. } \\
\text { 3. Teknologi pengurai sabut } \\
\text { kelapa masih tergantung } \\
\text { pada pikak lain }\end{array}$ \\
\hline OPPORTUNTTY $(O)$ & STRATEGIS-O & STRATEGI W-O \\
\hline $\begin{array}{l}\text { 1. Banyakanya limbah sabut } \\
\text { kelapa yang tidak } \\
\text { terpakai. } \\
\text { 2. Kebutuhan konsumen } \\
\text { akan produk ramah } \\
\text { lingkungan } \\
\text { 3. Banyaknya lulusan anak } \\
\text { disabilitas dan ibu rumah } \\
\text { tangga yang berpeluang } \\
\text { menjadi tenaga kerja. }\end{array}$ & $\begin{array}{l}\text { Menciptakan produk yang } \\
\text { bersifat tahan lama, memiliki } \\
\text { wangi yang dapat membuat } \\
\text { pikiran menjadi relax, solutif } \\
\text { untuk memnfastkan peluang } \\
\text { pasar yang ada, memenuhi } \\
\text { keinginan konsumen dan } \\
\text { merupakan industri kreatif } \\
\text { berbasis socio entregreneurship. }\end{array}$ & $\begin{array}{l}\text { Meminimalkan kelemahan } \\
\text { produk dengan } \\
\text { menggumakan bahan yang } \\
\text { kuat, tebal, desain yang } \\
\text { menarik, dan lebih praktis } \\
\text { untuk memanfaatkan } \\
\text { peluang pasar yang ada, } \\
\text { memenuhi keinginan } \\
\text { konsumen berbasis socio } \\
\text { entrepreneurship. }\end{array}$ \\
\hline THREATS $(T)$ & STRATEGIS-T & STRATEGI W-T \\
\hline $\begin{array}{l}\text { 1. Munculnya peasing } \\
\text { yang menghasilkan } \\
\text { produlk sejenis. } \\
\text { 2. Adanya produk } \\
\text { pengganti (subsitusi). } \\
\text { 3. Perkembangan } \\
\text { teknologi. } \\
\text { 4. Terdapat golongan } \\
\text { konsumen yang tidak } \\
\text { menvolkai aroma terani }\end{array}$ & $\begin{array}{l}\text { Menciptakan produk yang } \\
\text { bersifat tahan lama, memiliki } \\
\text { aroma terapi yang dapat } \\
\text { membuat pikiran menjadi lebih } \\
\text { relcox, solutif untuk mengatasi } \\
\text { ancaman yang ada yaitu } \\
\text { mumculnya pesaing, produk } \\
\text { pengganti, dan parksembangan } \\
\text { telonologi. }\end{array}$ & $\begin{array}{l}\text { Meminimalkan kelemahan } \\
\text { produk dengan } \\
\text { menggunakan bahan yang } \\
\text { kuat, tebal, desain yang } \\
\text { menarik dan lebih praktis } \\
\text { untuk mengatasi ancaman } \\
\text { yang ada yaitu munculnya } \\
\text { pasaing, produk pengganti } \\
\text { dan perkembadrgan }\end{array}$ \\
\hline
\end{tabular}

\section{Analisis Pasar dan Kondisi Geografis dan Demografis Usaha}

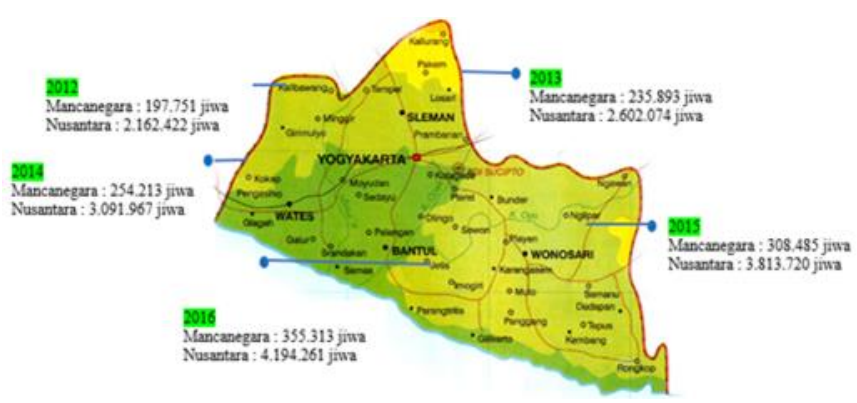

Gambar 3.2.Jumlah Wisatawan Yogyakarta

(Sumber: Statistik Kepariwisataan Yogyakarta 2016)

Menurut Badan Pusat Statistik (BPS) Republik Indonesia, perkembangan jumlah wisatawan yang berkunjung ke DIY menduduki posisi tertinggi di seluruh Indonesia dan mengalami kenaikan sebesar $41,89 \%$ dibandingkan tahun 2015 dan kenaikan tersebut merupakan yang tertinggi di Indonesia.

Secara geografis, usaha CO FIRE didirikan di Yogyakarta memberikan kemudahan serta keuntungan bisnis seperti mudahnya mendapatkan sumber bahan baku limbah sabut kelapa, sumber tenaga kerja yang berpotensi seperti ibu rumah tangga maupun anak disabilitas, kemudahan memasarkan $\mathrm{CO}$ FIRE karena Yogyakarta merupakan salah satu kota Pariwisata yang sering dikunjungi wisatawan. 
Secara demografis, berdasarkan hasil rekapan data Statistik Kepariwisataan Yogyakarta tahun 2016, jumlah kunjungan wisatawan yang berkunjung dari tahun 2012 hingga 2016 mengalami kenaikan. Dengan begitu usaha produk bantal CO FIRE memiliki potensi untuk dijadikan produk khas kebudayaan Yogyakarta dengan nuansa batik dengan target konsumen para wisatawan.

\section{Strategi Pemasaran}

Strategi pemasaran yang digunakan dalam pendirian usaha CO-FIRE adalah Segmentation, Targeting dan Positioning (STP) seperti berikut ini:

\section{Segmentation}

Tabel 3.2 Segmentasi Pasar CO FIRE

\begin{tabular}{|c|c|}
\hline $\begin{array}{l}\text { Segmentasi } \\
\text { Pasar }\end{array}$ & $\begin{array}{c}\text { Variabel } \\
\text { Segmentasi }\end{array}$ \\
\hline \multicolumn{2}{|c|}{ Segmentasi Georgafis } \\
\hline Wilayah & $\begin{array}{l}\text { Wilayah di } \\
\text { Indonesia dan } \\
\text { ASEAN }\end{array}$ \\
\hline Iklim & Tropis \\
\hline \multicolumn{2}{|c|}{ Segmentasi Demografis } \\
\hline Usia & 5-60 Tahun \\
\hline Jenis Kelamin & $\begin{array}{l}\text { Laki-laki dan } \\
\text { Perempuan }\end{array}$ \\
\hline Pekerjaan & $\begin{array}{c}\text { Semua } \\
\text { kalangan }\end{array}$ \\
\hline \multicolumn{2}{|c|}{ Segmentasi Psikografis } \\
\hline Gaya Hidup & Travelling \\
\hline Kepribadian & $\begin{array}{c}\text { Ekstrovert, } \\
\text { Aktif }\end{array}$ \\
\hline \multicolumn{2}{|c|}{ Segmentasi Tingkah Laku } \\
\hline $\begin{array}{l}\text { Manfaat Yang } \\
\text { Dicari }\end{array}$ & $\begin{array}{l}\text { Kepraktisan, } \\
\text { Kenyamanan } \\
\text { dan Keunikan }\end{array}$ \\
\hline $\begin{array}{c}\text { Tingkat } \\
\text { Penggunaan } \\
\end{array}$ & $\begin{array}{l}\text { Kenyamanan } \\
\text { tidur }\end{array}$ \\
\hline
\end{tabular}

\section{Targeting}

Target yang ditujukan CO FIRE

ditujukan kepada wisatawan laki-laki dan perempuan di daerah Yogyakarta dengan rentang usia 8 hingga 40 tahun, Hal ini dikarenakan usia yang konsumtif itu berada salam range usia antara 8 hingga 40 tahun baik laki-laki maupun perempuan.

\section{Positioning}

Keunikan produk dari CO FIRE yaitu mengolah limbah sabut kelapa menjadi suatu inovasi bantal kreatif dengan memeperkenalkan batik ciprat modern sebagai inovasi batik modern dan aksara jawa, serta adanya produk ragam bantal yang menggunakan sediaan aromaterapi untuk membuat pengguna nyaman.

\section{KESIMPULAN}

CO FIRE meupakan hasil inovasi pengolahan limbah sabut kelapa menjadi kreasi bantal yang terdapat dua jenis menggunakan motif aksara jawa maupun batik ciprat modern. Aromaterapi diberikan pada bahan utama yaitu sabut kelapa dan juga terdapat filter aromaterapi yang dapat diisi kembali ketika sudah habis sehingga pengguna dapat nyaman saat menggunakan bantal ini. Penjahitan produk sabut kelapa ini menggunakan socio entrepeneurship lulusan anak berkebutuhan khusus untuk meningkatkan pendapatan mereka secara finansial.

\section{DAFTAR PUSTAKA}

1. Barocelli E, Calcina F, Chiavarini M, Impicciatore M, Bruni R, Bianchi A, Vallabeni V. Antinociceptive and Gastroprotective Effect of Inhaled and Orally Administered Lavandulahybrida Reverchon "Grosso" Esensial oil. Science Direct 2004: 76; 213-223.

2. Butje, A., Repede, E., dan Shattell, M. M. (2008). Healing scents: An overview of clinical aromatherapy for emotional distress. Journal of Psychosocial Nursing \& Mental Health Services, 46(10), 46-52.

3. Budianta, A. (2010). Revitalisasi Pertanian Penggerak Utama Pembangunan Kawasan Perdesaan di Indonesia. Jurnal "Mektek" Tahun XII No.1, 2.

4. Hartini, S., Wijaya, A. B., Widjojo, N., Susilowati, M., \& Petriana, G. (2013). Pemanfaatan Serabut Kelapa Termodifikasi Sebagai Bahan Pengisi Bantal dan Matras. Prosiding Seminar Nasional Sains dan Pendidikan Sains VIII, Fakultas Sains dan Matematika, UKSW , 4(1), 1-7.

5. He, L., Huan, L., XiaoLan, L., AiGuo, Z., 2010, Chemical composition of lavender essential oil and its antioxidant activity and inhibition against rhinitis- related bacteria, African Journal of 
Microbiology Research Vol. 4 (4), pp. 309-313.

6. Humiras Hardi Purba, 2009, Inovasi Nilai Pelanggan dalam Perencanaan \& Pengembangan Produk, Yogyakarta : Graha IImu

7. Kusnanto. (2007). Manfaat Aromaterapi Lavender Terhadap Penurunan Insomnia pada Lansia . Jurnal Ners, 2(1).

8. Madu, Christian N. 2006. House of Quality (QFD) in a Minute; Chi Publishers Inc.

9. Muchtaridi, Penelitian Pengembangan Minyak Atsiri Sebagai Aromaterapi dan Potensinya Sebagai Produk Sediaan Farmasi, Jurnal Tek. Ind. Pert. Vol. 17(3),80-88.

10. Mulyawan, M., Setyowati, E., \& Widjaja, A. (2015). Surfaktan Sodium Ligno Sulfonat (SLS) dari Debu Sabut Kelapa. Jurnal Teknik ITS , 4(1), 1-3.

11. Setiawan, A. K. (2016). Strategi Meningkatkan Daya Saing UMKM Sektor Industri Makanan dan Minuman untuk Menyongsong MEA (Studi di Dinas Koperasi dan UKM dan Dinas Perindustrian dan Perdagangan Kota Malang) . Jurnal Universitas Brwijaya, 4(7).

12. Sofiani, V., Pratiwi, R., 2017, Riview artikel : Pemanfaatan minyak atsiri pada tanaman sebagai aromaterapi dalam sediaan, Fakultas Farmasi Universitas Padjadjaran, Farmaka Volume 14 No 2

13. Suroso, G. (2015). Masyarakat Ekonomi Asean (MEA) dan Perekonomian Indonesia. Jurnal Widyaiswara BPPK, 1-2.

14. Susanti. (2011). Perbedaan Tingkat Insomnia Lansia Sebelum dan Sesudah Latihan Relaksasi Otot Progresif (Progressive Muscle Relaxation) . BPSTW Ciparay Bandung UNPAD.

15. Susanti, L. (2015). Faktor-faktor yang Mempengaruhi Kejadian Insomnia di Poliklinik Saraf DR. M. Djamil Padang. Jurnal Kesehatan Andalas , 2.

16. Yuni Eko Feriyanto, Patar Jonathan Sipahutar, Mahfud, dan Pantjawarni Prihatini, 2013, Pengambilan Minyak Atsiri dari Daun dan Batang
Serai Wangi (Cymbopogon winterianus) Menggunakan Metode Distilasi Uap dan Air dengan Pemanasan Microwave, Jurnal Teknik Pomits. Vol. 2, No. 1, (2013) ISSN: 2337-3539 